\title{
Usprawnienie procesu gospodarczego metodą mapowania - studium przypadku
}

\section{Streamlining the economic process using the mapping method - a case study}

\author{
Marzena Bagińska \\ Szkoła Główna Handlowa w Warszawie, e-mail: marzena.baginska@doktorant.sgh.waw.pl, ORCID: 0000-0002-8228-3651
}

\begin{abstract}
Streszczenie
Mapowanie procesów jest interesującą i niezbyt skomplikowaną metodą poprawy usprawniania procesów w przedsiębiorstwie. Jest stosowana bardzo często przez kadrę zarządzającą, zwykle intuicyjnie. Celem artykułu było przedstawienie tejże metody, jej praktyczne zastosowanie w kontekście opracowania ulepszonego procesu oraz zidentyfikowania wąskich gardeł i nieciągłości w ramach istniejących procesów w organizacji. Jako metody badawcze zastosowano case study (studium przypadku), obserwację, wywiad (ekspercki i zogniskowany) oraz badania terenowe. Jako narzędzie badawcze wykorzystano mapowanie procesów. Do projektowania map procesów zastosowano dwie techniki: Flow Carting (przepływ procesu) oraz Value Stream Mapping - VSP (mapowanie strumienia wartości). Opracowanie ma walor empiryczny, wskazuje bowiem na zasadność identyfikowania i opisywania procesów, a także na ich doskonalenie. Na podstawie wyników przeprowadzonej pracy badawczej wyciągnięto wnioski, a także przedstawiono zalety i korzyści mapowania procesów oraz dodatkowo zaproponowano daleko idące działania naprawcze procesów.
\end{abstract}

Słowa kluczowe: mapa procesu, przepływ procesu, mapowanie strumienia wartości.

\begin{abstract}
Process mapping is an interesting and not very complicated method of process improvement in an enterprise. It is very often and usually intuitively used by the management staff. The aim of the article was to present this method, its practical application in the context of developing an improved process and identifying bottlenecks and discontinuities as part of existing processes in the organization. As research methods, a case study, observation, an interview (expert and skeleton) and field studies were used. Process mapping was used as a research tool. Two techniques were used to design process maps: Flow Carting and Value Stream Mapping VSP. The study has an empirical value, because it indicates the legitimacy of identifying and describing processes, as well as their improvement. Based on the results of the research work, conclusions were drawn, as well as the advantages and benefits of process mapping and the addition of far-reaching repair processes were proposed.
\end{abstract}

Keywords: process map, Flow Carting, Value Stream Mapping. 


\section{Wstęp}

Współczesne przedsiębiorstwa wciąż poszukują nowych rozwiązań i koncepcji systemowych umożliwiających podniesienie ich efektywności działania na współczesnym rynku ostrej konkurencji. Dlatego też tak ważne jest wybranie odpowiedniej strategii zarządzania przedsiębiorstwem - skoncentrowanie się na podejściu funkcjonalnym lub procesowym. Według R.W. Griffin, zarządzanie przedsiębiorstwem polega na harmonizowaniu działań wykonywanych na rzecz przedsiębiorstwa z zamiarem osiągnięcia jego celów w sposób sprawny, tzn. wykorzystując zasoby mądrze i bez zbędnego marnotrawstwa, oraz skuteczny, tzn. prowadzący do zamierzonego wyniku [Griffin 1996, s. 38].

Wśród nowoczesnych koncepcji i metod zarządzania wiele na pierwszym miejscu stawia poprawę oraz doskonalenie procesów. Wśród nich można wymienić: Reengineering, Total Quality Management (kompleksowe zarządzanie jakością), Benchmarking, Activity Based Costing (ABC), Activity Based Management (ABM), Balanced Scored Card (BSC), Just-In-Time (JIT), Kaizen, Kanban, Lean Management [Bitkowska 2009, s. 26].

Odpowiedzią zatem na wyzwania rynku może być odejście od zarządzania funkcjonalnego na rzecz podejścia procesowego. W literaturze przedmiotu podkreśla się, że analiza bilansu korzyści i ograniczeń struktur funkcjonalnych skłania do przyjęcia podejścia procesowego [Cyfert 2006, s. 22]. Podejście procesowe (w skrócie zarządzanie procesowe) to zarządzanie wysuwające na pierwszy plan aspekty dynamiczne i harmonizację procesową działań. Podejście to kładzie główny nacisk na zaspokojenie potrzeb klientów przedsiębiorstwa (czego wyrazem jest tworzenie procedur zarządzania: instrukcje, schematy przebiegu) [Trocki(b)]. Skupia się ono na zjawiskach dynamicznych zachodzących w organizacji [Grajewski 2014, s. 276], na koncentrowaniu przez menedżerów uwagi nie tylko na realizowanych funkcjach (np. zaopatrzenie, dystrybucja, fakturowanie), ale przede wszystkim na grupach zadań i czynnościach zorientowanych na zadowolenie klienta wewnętrznego i zewnętrznego, przysparzających mu wartość [Dobrowolska, 2011/2012]. Na tworzeniu organizacji nowego typu, opierających się na płaskiej strukturze i bazujących w dużej części na pracy zespołów, nieustannie adaptujących swoje działania do potrzeb i wymagań klientów.

\section{Proces i jego identyfikacja}

„Leksykon zarządzania” określa proces jako zespół następujących po sobie działań, pozostających w związku przyczynowo-skutkowym, wykonywany dla uzyskania zamierzonego rezultatu, przez zespół wykonawców na wielu stanowiskach pracy (w wielu komórkach organizacyjnych) [Leksykon zarzq̨dzania 2004]. M. Hammer oraz J. Champy określają proces jako zbiór działań, który ma jeden lub wiele rodzajów wejść i przekształca je w wyjścia przedstawiające wartość dla klienta [Hammer, Champy 1996, s. 46]. Aspekt wejścia oraz wyjścia procesu stanowi także element definicji zamieszczonej w jakościowej, opartej na tzw. „podejściu procesowym”, normie terminologicznej PN-EN ISO 9000:2000 [Polska Norma PN-EN ISO 9000:2000, p. 3.4.1], w której proces interpretowany jest jako „zbiór działań wzajemnie powiązanych lub wzajemnie oddziałujących, które przekształcają wejścia w wyjścia". W przywoływanej normie podkreśla się, że pożądany wynik działania osiąga się bardziej efektywnie, gdy zasoby i czynności związane z osiągnięciem tego wyniku traktowane i zarządzane są jako procesy [http://ioz.pwr.wroc.pl, Dobrowolska, wykład].

Istotę pojęcia procesu gospodarczego można zidentyfikować następująco [Grajewski 2003, s. 104; Nowosielski]:

- Każdy proces jest łańcuchem sekwencyjnych czynności, które transformują mierzalne wejścia (materiały, informacje, ludzi, urządzenia, metody) w mierzalne wyjścia (produkty, usługi, informacje) - polega zatem na dodaniu do zasileń nowej wartości (dodanej).

- Każdy proces ma mierzalny cel - najogólniej jest nim tworzenie wartości uznanej i zweryfikowanej przez odbiorcę, zawartej w produkcie, usłudze, informacji lub innym możliwym do zdefiniowania efekcie końcowym. W każdym procesie jest przetwarzany (wytwarzany) jeden obiekt (ustalenie przedmiotu procesu). Składniki procesu nietworzące wartości dodanej są eliminowane (koncentracja na tworzeniu wartości).

- Każdy proces może być powtarzany, co oznacza, że możliwe jest jego zapisanie w formie umożliwiającej odczytanie jego przebiegu przez realizatorów.

- Każdy proces ma dostawcę i klienta, a zatem jego granice wyznaczane są przez jakiś zdefiniowany rodzaj transakcji zakupu zasileń i sprzedaży wytworu; każdy proces rozpoczyna się i kończy dla określonego klienta (odbiorcy), który formułuje wymagania i korzysta z wyników (efektów) tego procesu (wyodrębnienie procesu).

- Każdy proces składa się z podprocesów, czynności i innych elementarnych składników (strukturalizacja procesu, hierarchia procesu).

- Każdy proces ma osobę odpowiedzialną za proces, swojego „właściciela (określenie odpowiedzialności za proces).

- Dla każdego procesu jest ustalona najkorzystniejsza (ze względu na czas i inne zasoby) struktura jego przebiegu (kształtowanie przebiegu procesu).

- Dla każdego procesu jest konieczne zapewnienie ze strony dostawców właściwego zabezpieczenia procesu (ustalenie z dostawcą wejścia do procesu).

Liczba szczebli hierarchii procesów w różnych modelowych rozwiązaniach waha się pomiędzy 1 a 6 [Obora 2008, s. 177-189]:

- 1 poziom - architektura procesów charakterystyczna dla porterowskiej koncepcji łańcucha wartości dodanej; przewiduje ona model organizacji powiązanej z otoczeniem zewnętrznym za pomocą wejść i wyjść;

- 2 poziomy - zakłada koncepcja reengineeringu, w której wyróżnia się procesy główne i tzw. podprocesy;

- 3 poziomy: typy procesów, kategorie procesów, elementy procesów;

- 4 poziomy [Cyfert 2006, s. 148, (za:) Harrington, Esseling, Nimwegen 1997, s. 1-31]: 1) procesy główne - obejmują zwykle więcej niż jedną funkcję w strukturze organizacyjnej, a ich wyniki mają istotny wpływ na sposób funkcjonowania organizacji; 2) subprocesy - będące elementami 
procesu głównego, które są realizowane w celu wspierania procesu głównego; 3) działania - czynności realizowane w ramach procesu lub subprocesu; działania są realizowane $w$ ramach jednostek organizacyjnych i są zwykle udokumentowane instrukcją; poziom zadań, stanowiących fragment albo składową działania; 4) zadania (makroprocesy) - odnoszą się do sposobu realizacji konkretnych przedsięwzięć);

- 4 poziomy [Cyfert 2006, s. 149 (w:) Stabryła (red.) 2006 (za:) Badiru, Ayeni 1993, s. 85]: system, procesy, podprocesy (subprocesy), zadania;

- 4 poziomy [Cyfert 2006, s. 149 (w:) Stabryła (red.) 2006 (za:) Jacka, Keller 2002, s. 23-251]: poziom jednostek, poziom zadań, poziom działań i poziom procedur;

- 4 poziomy [Trocki (w:) Leksykon zarządzania 2004, s. 556]: fazy procesów, procesy składowe, procesy cząstkowe i operacje;

- 5 poziomów [Cyfert 2006, s. 149, (w:) Stabryła (red.) 2006, (za:) Durlik 2004, s. 262-264, (w:) Romanowska, Trocki 2004]: megaprocesy, procesy, subprocesy, operacje, zabiegi;

- 6 poziomów [Cyfert 2006, s. 149, (w:) Stabryła (red.) 2006, (za:) Harmon 2003, s. 24, 114]: 1) poziom organizacji i środowiska, 2) poziom łańcucha wartości, 3) poziom procesów, 4) poziom subprocesów, 5) poziom działań, 6) poziom kroków (schematów).

Każda organizacja może zostać opisana jako system procesów, między którymi powstaje wiele wzajemnych zależności (relacji dostawca-klient). Taki system procesów nazywany jest często architekturą procesów [Nowosielski 2009, s. 187, (w:) Nowosielski (red.) 2009, (za:) Österle 1995, s. 137], która stanowi odpowiednik struktury organizacyjnej w organizacji funkcjonalnej [Nowosielski 2009, s. 187, (w:) Nowosielski (red.) 2009, (za:) Cyfert 2006, s. 5].

Identyfikacja procesów obejmuje dokonanie wyboru: procesów podstawowych, pomocniczych i zarządczych oraz mapowanie procesów (wizualizacja graficzna). Mapa procesów pokazuje procesy na najwyższym poziomie ogólności, przedstawia, jakie procesy występują w wyznaczonym obszarze działalności, oraz zależności pomiędzy nimi (np. które procesy są nadrzędne względem innych procesów) [Bitkowska 2009, s. 91]. Cele procesów, które są związane z zewnętrznym klientem, powinny wynikać z celów całej organizacji oraz oczekiwań i wymagań klientów [Rummler, Brache 2000, s. 50]. Czyli najważniejszym źródłem powinna być strategia organizacji, tj. długookresowa koncepcja funkcjonowania przedsiębiorstwa, określająca jego główne cele i sposoby ich osiągnięcia [Trocki 2012, s. 82]. Należy więc dążyć do osiągnięcia podstawowych parametrów - zamierzonego rezultatu, zakresu, kosztu i czasu realizacji projektu - na założonym ich poziomie. Sprowadza się to do prostej reguły: realizować proces dobrze (zamierzony rezultat), w całości (zakres), tanio (koszt) i szybko (czas) [Trocki (red.) 2011, s. 45].

W identyfikacji procesów, która pozwala zidentyfikować, jakie procesy są niezbędne w danej organizacji, aby klienci otrzymali oczekiwane świadczenia [Nowosielski S. (red.) 2008, s. 61 (za:) Schmelzer, Sesselmann 2003, s. 74], zalecane jest zastosowanie podejścia top-down (od góry do dołu) lub bottom-up (od dołu do góry) [Nowosielski S. (red.) 2008, s. 61].
W podejściu top-down wychodzi się od strategii przedsiębiorstwa. Zdefiniowane w strategii obszary działania i grupy klientów w połączeniu z wymogami klientów i ofertą produktową tworzą dane wyjściowe, również do zdefiniowania nowych, jeszcze niewystępujących w organizacji procesów. W tym podejściu najpierw identyfikuje się procesy podstawowe (kluczowe) i czynności wchodzące do nich, a w następnej kolejności procesy wspierające. W podejściu bottom-up postępuje się w odwrotnej kolejności. Wychodzi się od elementarnych czynności, realnie istniejących w przedsiębiorstwie procesów, usytuowanych na najniższym poziomie. Następnie poprzez ich agregowanie w większe grupy dochodzi się do pojedynczych procesów i makroprocesów. To podejście wychodzi od już istniejących procesów, a ich selekcja z punktu widzenia wymogów klientów, wkładu do tworzenia wartości dodanej dla przedsiębiorstwa czy jego celów jest w praktyce znacznie ograniczona lub nie ma w ogóle miejsca [Nowosielski (red.) 2008, s. 61].

\section{Mapowanie i mapa procesu}

\subsection{Mapowanie procesów i mapa procesu - definicje $i$ istota}

Definiowanie (projektowanie) procesów to sporządzanie opisu docelowego, wzorcowego przebiegu procesu. Odbywa się ono poprzez tzw. mapowanie procesów - czyli sporządzanie tzw. map procesów [Trocki (a), s. 69 slajd 138].

Mapa procesu jest to graficzny i werbalny opis przebiegu procesu, dokonany według określonego systemu opisu. Mapy procesów sporządza się najpierw dla istniejących przebiegów procesów (as-is) w celu poddania ich krytycznej analizie i ocenie, a następnie sporządza się (projektuje) ulepszoną, wzorcową wersję procesu (to-be). Obrazuje to rys. 1.

\begin{tabular}{|c|c|c|c|}
\hline \multicolumn{2}{|c|}{ AS - IS } & \multicolumn{2}{|c|}{ TO - BE } \\
\hline $\begin{array}{l}\text { Opis stanu } \\
\text { obecnego }\end{array}$ & $\begin{array}{l}\text { Opis obecnego } \\
\text { procesu }\end{array}$ & $\begin{array}{c}\text { Opracowanie } \\
\text { docelowego } \\
\text { procesu }\end{array}$ & $\begin{array}{c}\text { Ocena } \\
\text { docelowego } \\
\text { procesu }\end{array}$ \\
\hline $\mathrm{Co} ?$ & Dlaczego to? & Co? & Dlaczego to? \\
\hline Kiedy? & Dlaczego wtedy? & Kiedy? & Dlaczego wtedy? \\
\hline Kto? & Dlaczego oni? & Kto? & Dlaczego oni? \\
\hline Gdzie? & Dlaczego tam? & Gdzie? & Dlaczego tam? \\
\hline Jak? & Dlaczego tak? & Jak? & Dlaczego tak? \\
\hline
\end{tabular}

Rysunek 1. Definiowanie procesu

Źródło: [Trocki (a), s. 70 slajd 140].

Mapa procesu jest więc narzędziem umożliwiającym wizualizację kompleksu działań, ocenę ustrukturalizowania każdego procesu i podprocesu na jego obecnym etapie [Nowosielski (red.) 2008, s. 83, (za:) Lisiecka 2002, s. 243], stanowi dynamiczny obraz przedsiębiorstwa (w przeciwieństwie do schematu struktury organizacyjnej, który jest obrazem statycznym) [Nogalski, Czapiewski 2012, s. 174, (w:) Stabryła, Wawak (red.) 2012]. 
Mapy procesów - oddając przebieg wszystkich czynności w przedsiębiorstwie i wskazując osoby odpowiedzialne za realizację procesów - określają stan zarządzania przedsiębiorstwem (zarządzania jakością) i pozwalają odszukać ewentualne niedoskonałości procesów, tzw. białe plamy [Kister 2005, s. 31].

Obecnie mapy procesów używane są do wprowadzania zmian w funkcjonowaniu przedsiębiorstw podczas: organizowania funkcjonowania firmy w procesie restrukturyzacji; skracania czasu wykonywania procesów; zmniejszania kosztów wykonywania procesów; wdrażania zintegrowanych systemów informatycznych; wprowadzania systemów zarządzania przez jakość; przechodzenia na działalność gospodarczą z wykorzystaniem Internetu; tworzenia zintegrowanych łańcuchów dostaw [Bitkowska 2009, s. 97, za: Gruchman 2008].

Dysponując mapami procesów i zarządzając nimi, organizacja otwiera się na ciągłe doskonalenie procesów. Podczas gdy mierzenie jednostek organizacyjnych nie pozwala na wyciągnięcie wniosków, pomiar wydajności procesów może dostarczyć bardzo użytecznych wyników, zmierzających do zapoczątkowania zjawiska ciągłego doskonalenia [Bitkowska 2009, s. 98, (za:) Pawlak (red.) 2003, s. 50].

Sporządzanie mapy procesów dostarcza jasnych informacji o przebiegu procesów i osobach odpowiedzialnych za ich realizację. Skupienie się na procesach prowadzi do podważenia dotychczasowego podziału na funkcję i specjalizację na rzecz wielofunkcyjnych zespołów pracowników, które są powoływane na potrzeby konkretnego procesu i cechują się znaczną autonomią przy wypełnianiu zadań mających na celu wypracowanie rozwiązań zaspokajających wymagania klienta [Kister 2005, s. 25]. Określenie wymagań klientów, czyli zarówno elementów wejściowych, jak i elementów wyjściowych, oraz wnioski wyciągane z doświadczenia, przeglądów wewnętrznych oraz informacji napływających od klientów są podstawą doskonalenia procesów. Procentuje to całościowym spojrzeniem na organizację [Nowosielski (red.) 2009, s. 156].

\subsection{Przygotowanie map procesu}

Podczas opracowywania mapy procesu musimy określić jej szczegółowość. Mniej szczegółową mapę tworzymy, gdy przedstawiamy ogólne zasady funkcjonowania procesu (np. dla klienta czy kierownictwa), gdzie ważne jest ogólne zrozumienie funkcjonowania procesu. Bardziej szczegółową mapę stosuje się podczas wdrażania nowych wyrobów do produkcji lub gdy szukamy przyczyny problemu w procesie, w którym występuje wiele operacji (łącznie z transportem wewnętrznym itp.); czasem podczas tworzenia mapy procesów możemy zidentyfikować wiele miejsc, gdzie marnotrawiony jest czas (więc i pieniądze) lub istnieje zagrożenie, że wyroby niezgodne mogą być dostarczone do kolejnego procesu (lub do klienta) [Osiadacz 2011, s. 30-31].

Procedura sporządzenia mapy procesu obejmuje cztery fazy: (1) gromadzenie danych, (2) strukturalizację danych, (3) prezentację, (4) komunikację. Mapowania procesu zwykle nie realizuje jedna osoba. $\mathrm{W}$ praktyce jest to zwykle pewna grupa osób realizujących wyodrębniony projekt, realizowany w ra- mach przedsiębiorstwa $\mathrm{z}$ własnym kierownikiem projektu i interdyscyplinarnym zespołem projektowym, ewentualnie zespół taki funkcjonuje jako zespół podprojektu realizowanego w ramach większego projektu [Kasperek 2006, s. 59-60]. Do wykonania mapy procesu można zastosować wiele narzędzi, od zwykłej kartki z ołówkiem poprzez oprogramowanie typu Office, aż po specjalnie do tego celu stworzone oprogramowanie. Kolejno rysuje się poszczególne operacje w danym procesie i następnie łączy je ze sobą za pomocą strzałek [http://governica.com]. Tworzenie mapy procesu rozpoczyna się od zidentyfikowania wszystkich podmiotów biorących udział w procesie i wypisaniu ich w kolumnie po lewej stronie rysunku. Następnie rysuje się poziome linie, oddzielające poszczególne podmioty. Kiedy mamy już przygotowany schemat procesu, zespół (złożony z przedstawicieli wszystkich zaangażowanych działów, a tam, gdzie to możliwe, również podmiotów zewnętrznych, np. klientów, ekspertów) opisuje przebieg procesu przekształcenia określonych zasileń (np. złożenie zamówienia jest pierwszą czynnością przy mapowaniu procesu realizacji zamówienia) w kolejnych czynnościach aż do momentu stworzenia ostatecznego wyniku procesu (np. płatności przez klienta). Takie przedstawienie mapy umożliwia członkom zespołu znalezienie wszelkich głównych powiązań w procesie, pozwala określić czas konieczny do wykonania poszczególnych czynności oraz zidentyfikować wszelkie niedociągnięcia w procesie (nielogiczne, brakujące lub niepotrzebne czynności). Gdy zostały już określone cele dla kluczowych procesów, menedżerowie powinni upewnić się, że sposób zaprojektowania procesów daje możliwość efektywnej realizacji przyjętych celów. To właśnie przygotowanie mapy procesu (stan obecny jego realizacji) pozwala dokonać analizy i sprawdzenia tego, czy każdy z procesów i podprocesów jest właściwie ustrukturalizowany. Stan obecny oraz stan pożądany jest istotnym elementem projektów usprawniania procesów [Rummler, Brache 2000, s. 80-84].

Mapa procesu, po realizacji danego projektu, powinna znaleźć się wraz z teczką projektu w materiałach archiwalnych dotyczących realizacji tego projektu. Poza tym powinna być na bieżąco dostępna w bazie danych przedsiębiorstwa. Dlaczego jest to takie ważne? Po upływie pewnego czasu przedsiębiorstwo, nie zachowując mapy procesu, nie będzie potrafiło odtworzyć danego projektu w całości z jego wszystkimi praktycznymi uwarunkowaniami [Kasperek 2006, s. 69].

Proces mapowania odgrywa kluczową rolę w doskonaleniu procesów, a nie wymaga dużych nakładów finansowych. Stosowany język znaków i ikon jest zrozumiały zarówno dla kadry menedżerskiej i inżynieryjnej, jak i szeregowych pracowników. Mapa przepływu wartości dostarcza najważniejszych informacji odnośnie do czasu dostawy komponentów, czasu procesu oraz terminu dostarczenia gotowych produktów do klienta [Kraśnicka, Głód, Pawlak 2014, s. 445]. Dzięki zmapowaniu przepływu możemy zidentyfikować miejsca występowania marnotrawstwa i po wykonanej analizie zaprojektować sposób na ich zredukowanie, ograniczenie lub ich całkowitą eliminację [Osiadacz 2011, s. 30-31]. 


\section{Mapa procesu - studium przypadku i mapa procesu}

\subsection{Metodyka badań}

W jednej z warszawskich spółek o profilu handlowym i strukturze wielooddziałowej autorce niniejszego artykułu został zasygnalizowany dylemat dotyczący obiegu i rozliczeń gotówki. W miarę zagłębiania się $\mathrm{w}$ to zagadnienie okazało się, że problem jest wielowymiarowy i bardziej skomplikowany, niż pierwotnie zakładała to kadra zarządzająca. Dlatego też został powołany zespół ds. projektu, na czele którego stanęła autorka niniejszej pracy. Zespół składał się z ekspertów z różnych dziedzin, będących głównie pracownikami poszczególnych działów w przedsiębiorstwie, jak i osób współpracujących, m.in. strategicznych klientów oraz przedstawicieli zakładu informatyczno-wdrożeniowego. Zadania postawione przed zespołem to

1) skrócenie czasu wykonywania procesów;

2) wyeliminowanie marnotrawstwa;

3) zidentyfikowanie i wyeliminowanie dodatkowych problemów.

Jako metody badawcze wybrano obserwację, wywiad (ekspercki i zogniskowany) oraz badania terenowe. Jako narzędzie badawcze wykorzystano mapowanie procesów.

Do projektowania map procesów zastosowano dwie techniki: Flow Carting (przepływ procesu) oraz Value Stream Mapping - VSP (mapowanie strumienia wartości). Pierwsza z nich posłużyła do pokazania sekwencji wszystkich czynności niezbędnych do wykonania danego zadania - danej czynności. Metoda mapowania strumienia wartości zaś posłużyła usprawnieniu przepływu wartości w przedsiębiorstwie. Wyniki mapowania zapisywano w postaci tzw. map strumieni wartości (stanu obecnego i przyszłego) [Rummler, Brache 2000, s. 80-95].

Mapa procesu została skonstruowana $\mathrm{w}$ formie schematu blokowego, do którego budowy wykorzystano symbole [http:// pl.wikipedia.org] według G.A. Rummlera i A.P. Brache’a (obrazuje to rys. 2):
- $\quad$ operand - prostokąt, do którego wpisywane są wszystkie operacje z wyjątkiem instrukcji wyboru,

- $\quad$ predykat - romb, do którego wpisywane są wyłącznie instrukcje wyboru,

- $\quad$ etykieta - owal służący do oznaczania początku bądź końca sekwencji schematu (kończy, zaczyna lub przerywa/ przenosi schemat),

- $\quad$ strzałka - wskazuje jednoznacznie powiązania i ich kierunek.

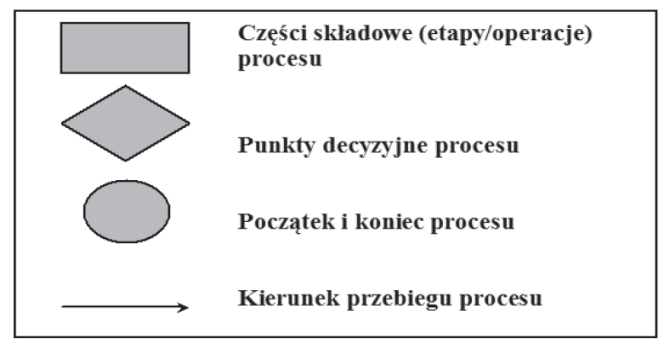

Rysunek 2. Symbole schematu blokowego według G.A. Rummlera i A.P. Brache'a

Źródło: [Trocki (a), s. 75 slajd 150].

\subsection{Mapa procesu - stan obecny}

Tworzenie mapy procesu rozpoczęto od zidentyfikowania i nazwania wszystkich podmiotów biorących udział w procesie, mianowicie: klient, dział handlowy w przedsiębiorstwie, dział księgowości w przedsiębiorstwie oraz ostateczny odbiorca procesu - bank. Ze względu na to, że nie wszyscy pracownicy działu handlowego i działu księgowości brali udział w tym procesie, dla potrzeb mapowania wyodrębniono dodatkowo grupy zawodów, które były w nie zaangażowane bezpośrednio, czyli: kierowców, przedstawicieli handlowych, fakturzystów i kasjerów. Poszczególne podmioty oddzielono poziomymi liniami. Następnie, korzystając z opisanych wcześniej metod badawczych, opisano przebieg procesu i naniesiono go na mapę. Efekty tych prac prezentuje rys. 3.

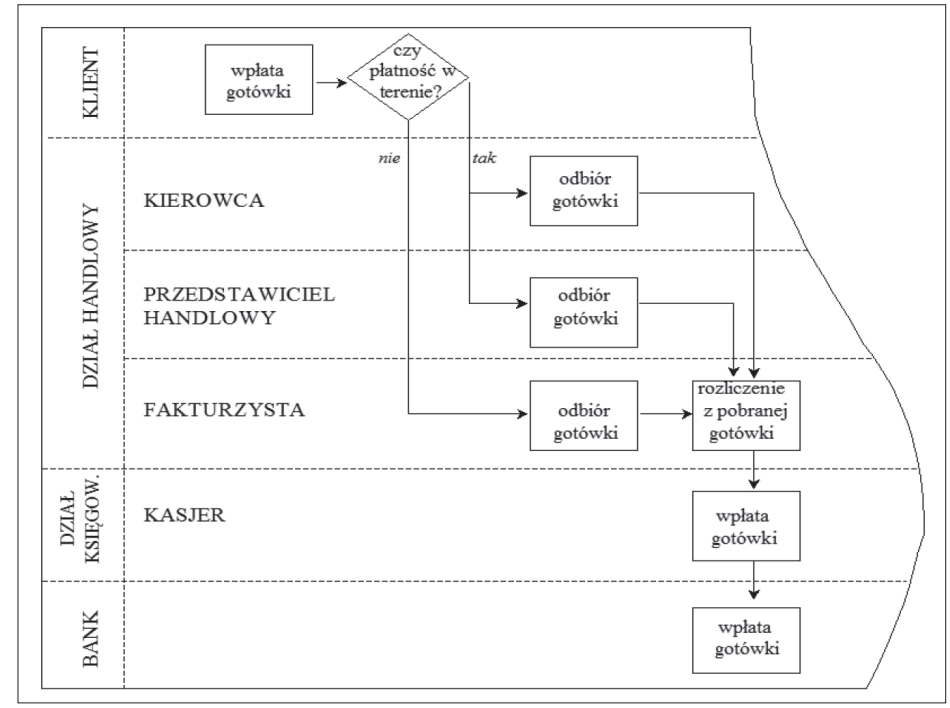

Rysunek 3. Mapa procesu - stan obecny mechanizmu rozliczenia gotówki w przedsiębiorstwie handlowym z siedzibą w Warszawie

Źródło: opracowanie własne. 
Tabela 1. Czas rozliczania gotówki w przedsiębiorstwie handlowym z siedzibą w Warszawie - stan obecny

\begin{tabular}{|c|c|c|c|c|c|c|}
\hline Stanowisko & $\begin{array}{l}\text { Poniedziałek } \\
\text { czas } w \text { godz. }\end{array}$ & $\begin{array}{c}\text { Wtorek } \\
\text { czas w godz.* }\end{array}$ & $\begin{array}{c}\text { Środa } \\
\text { czas w godz.* }\end{array}$ & $\begin{array}{c}\text { Czwartek } \\
\text { czas w godz.* }\end{array}$ & $\begin{array}{c}\text { Piątek } \\
\text { czas w godz.* }\end{array}$ & Razem \\
\hline przedst. handl. 1 & 23 & 23 & 23 & 23 & 1 & 93 \\
\hline przedst. handl. 2 & 23 & 23 & 23 & 23 & 1 & 93 \\
\hline przedst. handl. 3 & 23 & 23 & 23 & 23 & 1 & 93 \\
\hline przedst. handl. 4 & 23 & 23 & 23 & 23 & 1 & 93 \\
\hline przedst. handl. 5 & 23 & 23 & 23 & 23 & 1 & 93 \\
\hline przedst. handl. 6 & 23 & 23 & 23 & 23 & 1 & 93 \\
\hline przedst. handl. 7 & 23 & 23 & 23 & 23 & 1 & 93 \\
\hline przedst. handl. 8 & 23 & 23 & 23 & 23 & 1 & 93 \\
\hline przedst. handl. 9 & 23 & 23 & 23 & 23 & 1 & 93 \\
\hline przedst. handl. 10 & 23 & 23 & 23 & 23 & 1 & 93 \\
\hline przedst. handl. 11 & 23 & 23 & 23 & 23 & 1 & 93 \\
\hline przedst. handl. 12 & 23 & 23 & 23 & 23 & 1 & 93 \\
\hline przedst. handl. 13 & 23 & 23 & 23 & 23 & 1 & 93 \\
\hline przedst. handl. 14 & 23 & 23 & 23 & 23 & 69 & 161 \\
\hline przedst. handl. 15 & 21 & 21 & 21 & 21 & 69 & 153 \\
\hline przedst. handl. 16 & 95 & 71 & 47 & 23 & 167 & 403 \\
\hline przedst. handl. 17 & 95 & 71 & 47 & 23 & 167 & 403 \\
\hline przedst. handl. 18 & 95 & 71 & 47 & 23 & 167 & 403 \\
\hline kierowca 1 & 23 & 23 & 23 & 23 & 1 & 93 \\
\hline kierowca 2 & 23 & 23 & 23 & 23 & 1 & 93 \\
\hline kierowca 3 & 23 & 23 & 23 & 23 & 1 & 93 \\
\hline kierowca 4 & 23 & 23 & 23 & 23 & 1 & 93 \\
\hline kierowca 5 & 23 & 23 & 23 & 23 & 1 & 93 \\
\hline kierowca 6 & 23 & 23 & 23 & 23 & 1 & 93 \\
\hline kierowca 7 & 23 & 23 & 23 & 23 & 1 & 93 \\
\hline kierowca 8 & 23 & 23 & 23 & 23 & 1 & 93 \\
\hline kierowca 9 & 23 & 23 & 23 & 23 & 1 & 93 \\
\hline kierowca 10 & 21 & 21 & 21 & 21 & 67 & 151 \\
\hline kierowca 11 & 21 & 21 & 21 & 21 & 67 & 151 \\
\hline kierowca 12 & 21 & 21 & 21 & 21 & 67 & 151 \\
\hline kierowca 13 & 21 & 21 & 21 & 21 & 67 & 151 \\
\hline kierowca 14 & 21 & 21 & 21 & 21 & 67 & 151 \\
\hline kierowca 15 & 21 & 21 & 21 & 21 & 67 & 151 \\
\hline kierowca 16 & 21 & 21 & 21 & 21 & 67 & 151 \\
\hline kierowca 17 & 21 & 21 & 21 & 21 & 67 & 151 \\
\hline kierowca 18 & 21 & 21 & 21 & 21 & 67 & 151 \\
\hline fakturzysta 1 & 1 & 1 & 1 & 1 & 1 & 5 \\
\hline fakturzysta 2 & 1 & 1 & 1 & 1 & 1 & 5 \\
\hline fakturzysta 3 & 1 & 1 & 1 & 1 & 1 & 5 \\
\hline fakturzysta 4 & 1 & 1 & 1 & 1 & 1 & 5 \\
\hline fakturzysta 5 & 21 & 21 & 21 & 21 & 69 & 153 \\
\hline fakturzysta 6 & 21 & 21 & 21 & 21 & 69 & 153 \\
\hline fakturzysta 7 & 21 & 21 & 21 & 21 & 69 & 153 \\
\hline razem & 1091 & 1019 & 947 & 875 & 1475 & 5407 \\
\hline
\end{tabular}

* Liczony od momentu zakończenia obsługiwania przez pracownika ostatniego klienta do momentu wpłaty gotówki przez kasjera do banku (w zaokrągleniu do pełnej godziny).

Źródło: opracowanie własne. 
Głównym problemem, który identyfikowano, był czas, jaki mijał od momentu odebrania gotówki od klienta do momentu wpływu należności na konto bankowe spółki (tab. 1). Szczególnie stanowiło to prawdziwy dylemat w przypadku oddziałów organizacji, oddalonych nawet 50-60 km od miejsca zamieszkania kierowców i przedstawicieli handlowych, którzy głównie ze względu na koszty transportu odwiedzali macierzysty oddział z częstotliwością raz na tydzień. W tych przypadkach gotówka pobierana przez pracowników od klientów przez cały tydzień była dostarczana do przedsiębiorstwa z dużym opóźnieniem. Ponadto pracownicy ci, gdy przybyli już do oddziału spółki, rozliczali się z gotówki dopiero na koniec dnia swojej pracy - w praktyce ten sposób rozliczeń powodował, że w danym dniu kasjerka nie była w stanie przeliczyć i dostarczyć gotówki do banku. To powodowało kolejny dzień opóźnienia. Rzutowało to na bieżącą płynność finansową organizacji - powodowało zatory płatnicze i brak możliwości bieżącej realizacji swoich zobowiązań.

Kolejną ważną kwestią były nieprawidłowości w rozliczeniach, dokonywane przez osoby mające kontakt z gotówką jeżeli chodzi zarówno o kwoty, jak i terminowość rozliczania należności. Z tych względów idealnym rozwiązaniem byłoby rozliczanie pracownika już w momencie odbioru gotówki od klienta.

Następny problem to bezpieczeństwo gotówki - rozpatrywane w dwóch wymiarach: gotówki pozostawianej na noc w sejfie lub kasie pancernej (mimo wszystko istniała możliwość kradzieży, tym bardziej że w przeszłości zdarzały się już takie incydenty), po drugie, to bezpieczeństwo transportu przez kierowcę i przedstawiciela handlowego do oddziału przedsiębiorstwa, a następnie bezpieczeństwo transportu dużej wartości gotówki przez kasjera do banku (bezpieczeństwo zarówno środków pieniężnych, jak i ludzi).
Dodatkowo klienci zasygnalizowali oczekiwania co do chęci posiadania wiedzy na temat swojego stanu rozliczeń w momencie składania zamówienia lub dokonywania zapłaty za towar.

Zadaniem zespołu stało się więc stworzenie nowego schematu rozliczeń w przedsiębiorstwie. Takiego, który:

- skróciłby czas przepływu gotówki od klienta do banku;

- zaoszczędziłby czas niezbędny do dokonania całego procesu;

- wykluczyłby możliwości popełnienia przez pracowników, mających kontakt z gotówką, czynu zabronionego w rozumieniu kodeksu karnego;

- zwiększyłby bezpieczeństwo przechowywanej gotówki;

- zwiększyłby bezpieczeństwo transportowanej gotówki;

- zwiększyłby zdolność reakcji na zapotrzebowanie klienta (np. problem wydruków KP w terenie, konieczność rozliczenia klienta w systemie informatyczno-rozliczeniowym w momencie wizyty u klienta, a nie po powrocie do oddziału);

- w dalszej perspektywie czasowej przyniósłby realne oszczędności (w rozumieniu kosztowym);

- uwzględniałby przepisy ustawy o rachunkowości oraz nie był sprzeczny z innymi przepisami prawa.

\subsection{Mapa procesu - stan pożądany}

W dalszej kolejności przygotowano mapę procesów - „stan pożądany", w której starano się wyeliminować wszelkie problemy zauważone wcześniej i przedstawione na mapie „stan obecny”. Mapę tę przedstawia rys. 4 oraz tab. 2 .

Dla przejrzystego zobrazowania przebiegu procesów z obu map przygotowano jeden wykres, na którym porównano mapę

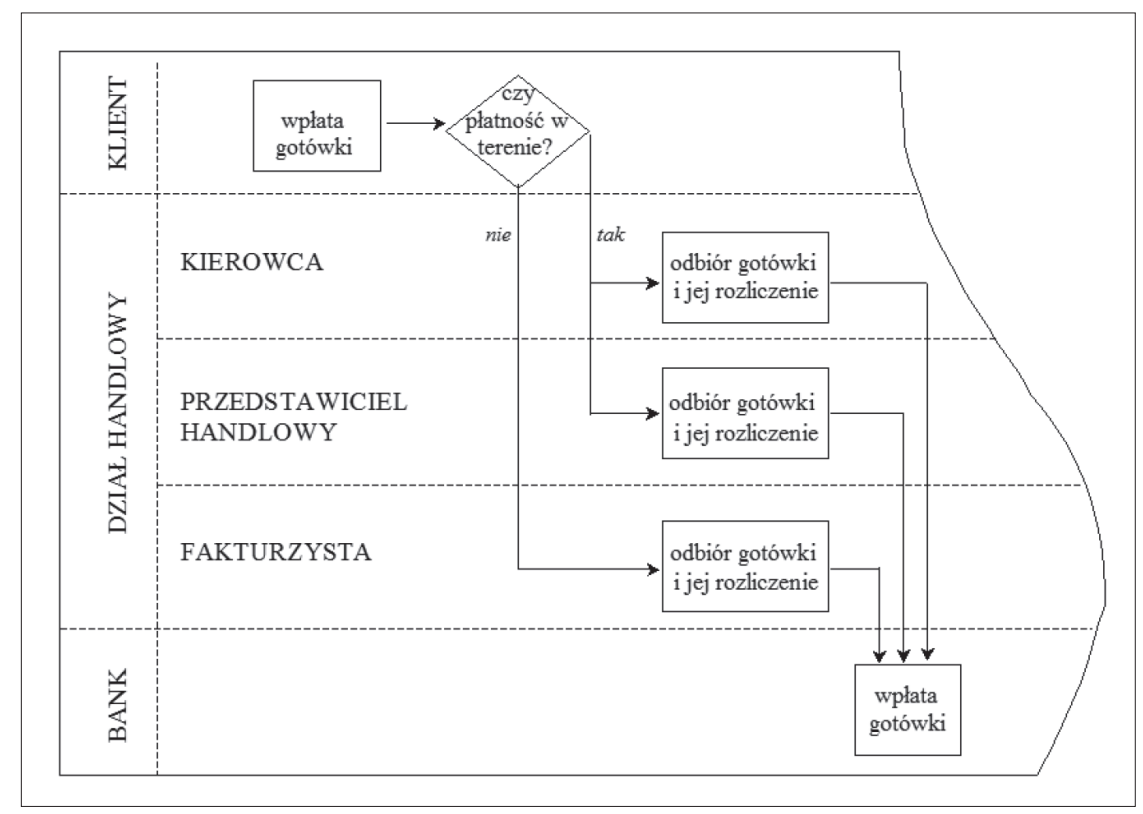

Rysunek 4. Mapa procesu - stan pożądany mechanizmu rozliczenia gotówki w przedsiębiorstwie handlowym z siedzibą w Warszawie

Źródło: opracowanie własne. 
Tabela 2. Czas rozliczania gotówki w przedsiębiorstwie handlowym z siedzibą w Warszawie - stan pożądany

\begin{tabular}{|c|c|c|c|c|c|c|}
\hline Stanowisko & $\begin{array}{l}\text { Poniedziałek } \\
\text { czas } w \text { godz.* }\end{array}$ & $\begin{array}{c}\text { Wtorek } \\
\text { czas w godz.* }\end{array}$ & $\begin{array}{c}\text { Środa } \\
\text { czas w godz.* }\end{array}$ & $\begin{array}{c}\text { Czwartek } \\
\text { czas w godz.* }\end{array}$ & $\begin{array}{c}\text { Piątek } \\
\text { czas w godz.* }\end{array}$ & Razem \\
\hline przedst. handl. 1 & 1 & 1 & 1 & 1 & 1 & 5 \\
\hline przedst. handl. 2 & 1 & 1 & 1 & 1 & 1 & 5 \\
\hline przedst. handl. 3 & 1 & 1 & 1 & 1 & 1 & 5 \\
\hline przedst. handl. 4 & 1 & 1 & 1 & 1 & 1 & 5 \\
\hline przedst. handl. 5 & 1 & 1 & 1 & 1 & 1 & 5 \\
\hline przedst. handl. 6 & 1 & 1 & 1 & 1 & 1 & 5 \\
\hline przedst. handl. 7 & 1 & 1 & 1 & 1 & 1 & 5 \\
\hline przedst. handl. 8 & 1 & 1 & 1 & 1 & 1 & 5 \\
\hline przedst. handl. 9 & 1 & 1 & 1 & 1 & 1 & 5 \\
\hline przedst. handl. 10 & 1 & 1 & 1 & 1 & 1 & 5 \\
\hline przedst. handl. 11 & 1 & 1 & 1 & 1 & 1 & 5 \\
\hline przedst. handl. 12 & 1 & 1 & 1 & 1 & 1 & 5 \\
\hline przedst. handl. 13 & 1 & 1 & 1 & 1 & 1 & 5 \\
\hline przedst. handl. 14 & 1 & 1 & 1 & 1 & 1 & 5 \\
\hline przedst. handl. 15 & 1 & 1 & 1 & 1 & 1 & 5 \\
\hline przedst. handl. 16 & 1 & 1 & 1 & 1 & 1 & 5 \\
\hline przedst. handl. 17 & 1 & 1 & 1 & 1 & 1 & 5 \\
\hline przedst. handl. 18 & 1 & 1 & 1 & 1 & 1 & 5 \\
\hline kierowca 1 & 1 & 1 & 1 & 1 & 1 & 5 \\
\hline kierowca 2 & 1 & 1 & 1 & 1 & 1 & 5 \\
\hline kierowca 3 & 1 & 1 & 1 & 1 & 1 & 5 \\
\hline kierowca 4 & 1 & 1 & 1 & 1 & 1 & 5 \\
\hline kierowca 5 & 1 & 1 & 1 & 1 & 1 & 5 \\
\hline kierowca 6 & 1 & 1 & 1 & 1 & 1 & 5 \\
\hline kierowca 7 & 1 & 1 & 1 & 1 & 1 & 5 \\
\hline kierowca 8 & 1 & 1 & 1 & 1 & 1 & 5 \\
\hline kierowca 9 & 1 & 1 & 1 & 1 & 1 & 5 \\
\hline kierowca 10 & 1 & 1 & 1 & 1 & 1 & 5 \\
\hline kierowca 11 & 1 & 1 & 1 & 1 & 1 & 5 \\
\hline kierowca 12 & 1 & 1 & 1 & 1 & 1 & 5 \\
\hline kierowca 13 & 1 & 1 & 1 & 1 & 1 & 5 \\
\hline kierowca 14 & 1 & 1 & 1 & 1 & 1 & 5 \\
\hline kierowca 15 & 1 & 1 & 1 & 1 & 1 & 5 \\
\hline kierowca 16 & 1 & 1 & 1 & 1 & 1 & 5 \\
\hline kierowca 17 & 1 & 1 & 1 & 1 & 1 & 5 \\
\hline kierowca 18 & 1 & 1 & 1 & 1 & 1 & 5 \\
\hline fakturzysta 1 & 1 & 1 & 1 & 1 & 1 & 5 \\
\hline fakturzysta 2 & 1 & 1 & 1 & 1 & 1 & 5 \\
\hline fakturzysta 3 & 1 & 1 & 1 & 1 & 1 & 5 \\
\hline fakturzysta 4 & 1 & 1 & 1 & 1 & 1 & 5 \\
\hline fakturzysta 5 & 1 & 1 & 1 & 1 & 1 & 5 \\
\hline fakturzysta 6 & 1 & 1 & 1 & 1 & 1 & 5 \\
\hline fakturzysta 7 & 1 & 1 & 1 & 1 & 1 & 5 \\
\hline razem & 43 & 43 & 43 & 43 & 43 & 215 \\
\hline
\end{tabular}

* Liczony od momentu zakończenia obsługiwania przez pracownika ostatniego klienta do momentu wpłaty gotówki przez kasjera do banku (w zaokrągleniu do pełnej godziny).

Źródło: opracowanie własne. 


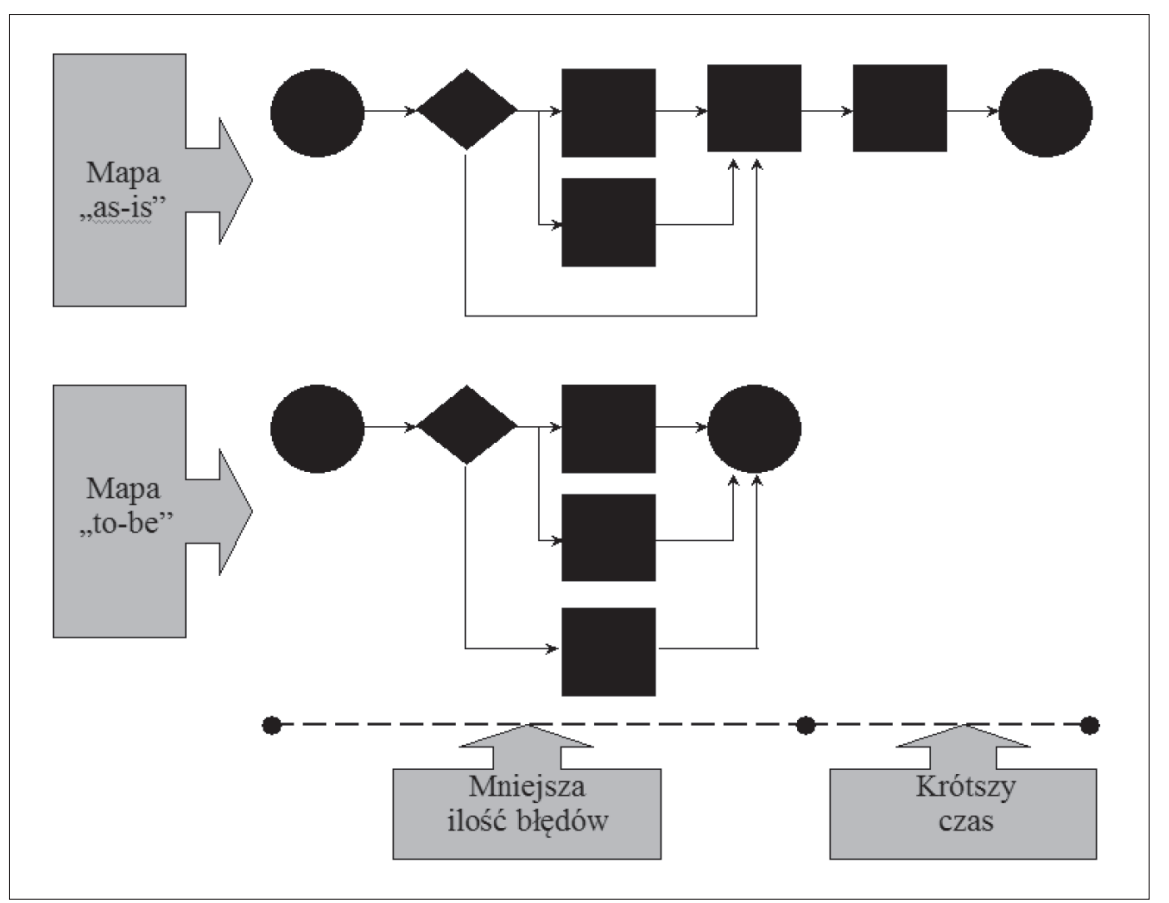

Rysunek 5. Porównanie mapy procesu as-is z mapą to-be

Źródło: opracowanie własne.

procesu „stan obecny” (mapa as-is) z mapą procesu „stan pożądany" (mapa to-be). Graficznie prezentuje to rys. 5.

\section{Wyniki badań i korzyści wynikające $\mathrm{z}$ mapowania procesu}

Interpretując mapy procesów oraz analizując studium przypadku, widzimy, że dzięki mapowaniu strumienia wartości:

a) zobrazowano przebieg procesów;

b) stworzono czytelny, przyjazny dla użytkowników, opis procesów, pozwalający na zrozumienie ich zarówno przez specjalistów, jak i osoby postronne, zastosowanie zaś symboli schematu blokowego według G.A. Rummlera i A.P. Brache'a (stosowanych w mapie procesów i znanych w wielu krajach) znakomicie ułatwia komunikację oraz umożliwia odczytanie mapy nawet za granicą (możliwe jest przedstawienie większości procesów za pomocą międzynarodowych symboli);

c) zastosowano kompleksowe podejście do procesu i analizę przebiegu procesu z punktu widzenia ustalonego celu;

d) uproszczono struktury całego procesu oraz jego przebiegu - ujednolicono dla wszystkich pracowników przejście danej czynności przez proces (rozliczenie i wpłata gotówki do banku) - tj. w przeliczeniu na jednostkowego pracownika to 5 godzin tygodniowo;

e) skrócono czas przejścia danej czynności przez proces oraz znacznie skrócono cały proces;

f) zidentyfikowano kluczowe operacje $w$ danym procesie oraz określono niezbędne wejścia i wyjścia dla danej operacji oraz ustalono, które operacje są nieskuteczne;

g) skoncentrowano się na zredukowaniu marnotrawstwa, a w ostatecznie zlikwidowano marnotrawstwo - przede wszystkim wyeliminowano marnotrawstwo czasu, tj. długi czas transferu gotówki, skrócono czas obsługi poszczególnych pracowników przedsiębiorstwa, wykluczono bezzasadne koszty zakupu niektórych materiałów biurowych, obniżono koszty bezcelowego utrzymania zbędnych pracowników);

h) doprowadzono do zmniejszenia liczby błędów: błędy rachunkowo-księgowe niecelowe i niezamierzone (np. wynikające z pośpiechu osób dokonujących rozliczeń lub liczących gotówkę, będące następstwem dokonywania rozliczeń przez kilka różnych osób), błędy rachunkowo-księgowe celowe i zamierzone (dokonywane np. przez osoby nieuczciwe, dążące do osiągnięcia osobistych korzyści majątkowych, czyny zabronione w rozumieniu kodeksu karnego) oraz błędy traktowane jako oczywiste omyłki pisarskie;

i) ograniczono biurokrację, np. wyeliminowano tworzenie dodatkowej (zbędnej z punktu widzenia zarządzania procesowego), często dublującej się dokumentacji magazynowo-rozliczeniowej oraz rozliczeniowo-księgowej; przeszkolono pracowników w zakresie prawidłowości wypełniania dokumentów magazynowo-księgowych oraz księgowo-finansowych (np. przeszkolono pracowników działu księgowości i przedstawiono, że np. sprzedaż towaru za gotówkę nie wymaga czytelnego podpisu klienta na fakturze, sprzedaż towaru na termin nie wymaga pieczątki klienta na fakturze itd. - do tej pory błędne wyobrażenie pracowników księgowości i idące za tym dokładanie pracy pracownikom terenowym, którzy parokrotnie musieli poprawiać dokumenty księgowo-finansowe, by sprostać tym absurdalnym wymaganiom, powodowało wydłużenie procesu, tj. pracownicy terenowi swój czas marnotrawili 
na zbędne poprawki, zamiast szybciej wrócić do oddziału, by zdążyć w czasie pracy kasjerki rozliczyć się z pobranej gotówki);

j) pracownikom wchodzącym w skład zespołu ds. projektu przekazano władzę na etapie identyfikacji i realizacji całego procesu;

k) doprowadzono do obniżenia kosztów funkcjonowania organizacji w dłuższej perspektywie czasu, np. ograniczono ilość zużywanego papieru i tonera - dokumenty drukowane wielokrotnie na różnych stanowiskach pracy bądź wypisywane ręcznie w kilku egzemplarzach; drogie bloczki KP, KW, RK zastąpiono tańszymi wydrukami z zakupionych kas; wprowadzony nowy system kontroli uniemożliwia (a na pewno ograniczył) możliwość podejmowania działań niezgodnych z prawem;

l) identyfikowano operacje zbędne (nieprzynoszące wartości dodanej) oraz wyeliminowano zbędne czynności, takie jak np. liczenie gotówki przez dodatkowego pracownika, opieczętowywanie (ostemplowanie druków w kilku egzemplarzach numeratorem oraz pieczątką firmową) i przygotowywanie (dla kierowców i przedstawicieli handlowych) druków ścisłego zarachowania (KP - kasa przyjmie, KW - kasa wypłaci, RK - raporty kasowe) oraz prowadzenie ewidencji przychodu i rozchodu tych druków; wyeliminowanie zbędnych ogniw to możliwość oszczędzania przez przedsiębiorstwo;

m) zredukowano zbędne stanowiska pracy;

n) ustalono i wyeliminowano wąskie gardła, np. na tych etapach procesu, gdzie pracownicy mogą dopuścić się czynu zabronionego w rozumieniu kodeksu karnego, wzmożono kontrolę oraz zastosowano inne zabezpieczenia typu natychmiastowe rozliczanie gotówki w momencie jej otrzymania od klienta czy systematyczne codzienne rozliczanie i wpłacanie do banku utargu z danego dnia;

o) wprowadzono lepszą i bardziej przejrzystą możliwość kontroli - utworzono nowe stanowisko pracy, jedno w całym przedsiębiorstwie, gdzie dokonuje się codziennej kontroli wpłat (ilościowo i wartościowo) dokonanych przez wszystkich pracowników mających dostęp do gotówki; reakcja pracownika na wszelkie nieprawidłowości jest natychmiastowa;

p) opracowano nowy, bardziej efektywny i motywujący, system wynagradzania kierowców i przedstawicieli handlowych;

q) wprowadzono system pomiaru efektywności pracy, który stał się nieodzownym elementem procesu umożliwiającym ograniczenie i wyeliminowanie marnotrawstwa czasu i zbędnych materiałów biurowych oraz zredukowania zbędnych stanowisk pracy;

r) we współpracy z działem księgowości i działem prawnym opracowano nowy, ulepszony regulamin rozliczeń pt. „Instrukcja polityki kasowej", z którą zapoznano wszystkich pracowników mających dostęp do gotówki - stał się on swoistą instrukcją, gdzie krok po kroku czytelnie przedstawiono pracownikom schemat pobierania i rozliczania gotówki oraz prawidłowego wypełniania dokumentacji; dzięki temu ograniczono możliwość popełniania błędów przez pracowników oraz ujednolicono wewnętrzne przepisy obowiązujące we wszystkich oddziałach Spółki; s) zidentyfikowano i rozwiązano inne istotne problemy (np. problem wydruków KP w terenie, konieczność rozliczenia klienta $w$ systemie informatyczno-rozliczeniowym w momencie wizyty u klienta, a nie po powrocie z trasy, bezpieczeństwo gotówki i pracowników, możliwość bezprowizyjnej wpłaty gotówki o każdej porze dnia i nocy w każdym oddziale banku na terenie RP);

t) dzięki szybszej rotacji gotówki polepszyły się wskaźniki płynności i rentowności przedsiębiorstwa, a tym samym skończyły się zatory płatnicze, poprawiła się zdolność bieżącej realizacji zobowiązań (w tym np. przedpłata za towar), co przełożyło się na możliwość negocjowania lepszych cen i warunków zakupu towarów;

u) dzięki mapowaniu i poszukiwaniu kreatywnych pomysłów pojawiła się możliwość łatwiejszego wdrożenia nowych (często innowacyjnych) rozwiązań w przedsiębiorstwie:

- ograniczono lub wyeliminowano przechowywanie gotówki przez pracowników (w tym w sejfach w oddziałach spółki),

- zwiększono bezpieczeństwo transportowanej gotówki poprzez przewóz przez pracowników tylko jednodniowego utargu; dodatkowo wyposażono auta w kasety antykradzieżowe; zmieniono politykę pozostawiana gotówki na noc w sejfach i kasach pancernych,

- $\quad$ wprowadzono obowiązek codziennego rozliczania się kierowców, przedstawicieli i fakturzystów oraz dostarczania bezpośrednio przez te osoby rozliczonej gotówki danego dnia do banku (najpóźniej rano dnia następnego) - w tym celu podpisano stosowne dodatkowe umowy z jednym z największych banków w Polsce, co pozwoliło pracownikom przedsiębiorstwa wpłatę gotówki w jakimkolwiek oddziale banku mającego gęstą sieć placówek na terenie całej RP; umożliwiono pracownikom korzystanie z nocnych wrzutni bankowych w miejscowościach najczęściej przez nich odwiedzanych - dzięki temu pracownicy mają możliwość dokonywania wpłat bezpośrednio w kasie banku lub korzystania z wrzutni zarówno podczas dnia pracy, jak i wieczorem lub rano, gdy kasa banku jest nieczynna,

- zmieniono sposób rozliczeń pracowników spółki w banku - m.in. poprzez zaopatrzenie ich w kodowane koperty, które są rozkodowywane przez bank, wpłata zaś, dokonana nawet poprzez wrzutnię, identyfikowana jest imiennie przez osobę wpłacającą i automatycznie dekretowana na rachunku bankowym spółki,

- przedstawicieli handlowych i kierowców wyposażono w pockety (palmtopy) - dzięki tym urządzeniom, mającym zdalny dostęp do systemu informatyczno-rozliczeniowego, pracownik ma obowiązek na bieżąco rozliczać się z pobranej gotówki,

- przedstawicieli handlowych i kierowców wyposażono w małe kasy przenośne, służące do bezpośredniego wydruku dowodów KP, KW i raportów kasowych z systemu informatyczno-rozliczeniowego,

- dzięki wprowadzonym pocketom (palmtopom) pracownik jest w stanie na bieżąco poinformować klienta o stanie zadłużenia, dzięki czemu świadomy klient może złożyć większe zamówienie, pracownik spółki zaś zainkasować zaległą należność od klienta. 


\section{Zakończenie}

Każda organizacja jest zbiorem wzajemnie przeplatających się procesów, orientacja procesowa zaś zaleca całościowe myślenie o procesach jako powiązanych ze sobą czynnościach. Ich identyfikacja pozwala na lepsze zrozumienie tworzenia wartości, a ich usprawnienie i stałe doskonalenie zwiększa efektywność funkcjonowania organizacji i stopień zadowolenia klientów wewnętrznych i zewnętrznych [Nowosielski (red.) 2008, s. 40].

Zarządzanie procesami, ich doskonalenie stwarza konieczność zobrazowania ich przebiegu przez mapowanie procesów. Wyniki analizy studium przypadku wykazały, że mapy procesów są doskonałym narzędziem służącym do usprawniania przebiegu procesu. Pozwalają na analizę przebiegu procesu z punktu widzenia ustalonego celu oraz na zidentyfikowanie wąskich gardeł i nieciągłości.

Mapowanie procesów jest narzędziem stosunkowo prostym (choć wymagającym dogłębnej analizy problemów, wyciągnięcia prawidłowych wniosków i wdrożenia właściwych rozwiązań) i stosunkowo tanim (nie mówimy tu kosztach wdrożenia zmian), którego wykonanie można zlecić w formie outsourcingu zewnętrznej firmie lub przeprowadzić we własnym zakresie.

Należy podkreślić, że wnioski z badań prowadzonych nad mapowaniem procesów, a co za tym idzie - przedstawione zalety i korzyści mapowania, nie stanowią katalogu zamkniętego. W obszarze badań mogą znaleźć się procesy, które wniosą do nauki kolejne rozwiązania i kolejne ciekawe pomysły rozwiązywania problemów.

\section{Literatura}

Badiru A.B., Ayeni B.J., 1993, Practitioner's Guide to Quality and Process Improvement, Springer.

Bitkowska A., 2009, Zarządzanie procesami biznesowymi w przedsiębiorstwie, Vizja Press \& IT, Warszawa.

Cyfert S., 2006, Architektura organizacji procesowej, Wydawnictwo Akademii Ekonomicznej w Krakowie, Kraków.

Cyfert S., 2006, Strategiczne doskonalenie architektury procesów w zarządzaniu przedsiębiorstwem, AE, Poznań.

Cyfert S., 2012, Granice organizacji, Wyd. Uniwersytetu Ekonomicznego w Poznaniu, Poznań.

Cyfert S., 2014, System granic architektury procesów organizacji - determinanty kształtowania, Wyd. Uniwersytetu Ekonomicznego we Wrocławiu, Wrocław.

Durlik I., 2004, Projektowanie techniczno-organizacyjne procesów biznesowych $w$ warunkach high-technology, Wyd. SGH, Warszawa.

Grajewski P., 2003, Koncepcja struktury organizacji procesowej, TNOiK Dom Organizatora, Torun.

Grajewski P., 2007, Organizacja procesowa. Projektowanie i konfiguracja, PWE, Warszawa.

Grajewski P., 2014, Przesłanki podejścia procesowego do projektowania i zarządzania organizacją, Wyd. Uniwersytetu Ekonomicznego we Wrocławiu, Wrocław.

Griffin RW., 1996, Podstawy zarządzania organizacjami, Wydawnictwo Naukowe PWN, Warszawa.
Hammer M., Champy J., 1996, Reengineering w przedsiębiorstwie, Neumann Management Institute, Warszawa.

Harmon P., 2003, Business Process Change, A Manager's Guide to Improving, Redesigned and Automating Processes, Morgan Kaufman Publishers, San Francisco.

Harrington H.J., Esseling E.K.C., Nimwegen H., 1997, Business Process Improvement Workbook. Documentation, Analysis, Design, and Management of Business Process Improvement, McGraw-Hill, New York.

Jacka J.M., Keller P.J., 2002, Business Process Mapping: Improving Customer Satisfaction, Wiley, NY, USA.

Kasperek M., 2006, Planowanie i organizacja projektów logistycznych, Wydawnictwo Akademii Ekonomicznej, Katowice.

Kasprzak T. (red.), 2005, Modele referencyjne w zarządzaniu procesami biznesu, Difin, Warszawa.

Kister A., 2005, Zarzązanie kosztami jakości, Oficyna Ekonomiczna, Kraków.

Kraśnicka T., Głód G., Pawlak G., 2014, Ewolucja koncepcji lean management $i$ jej zastosowanie $w$ przedsiębiorstwach $w$ Polsce, Marketing i Rynek, nr 5.

Leksykon zarządzania, Difin, Warszawa 2004.

Lichtarski J., Nowosielski S., Osbert-Pociecha G., Tabaszewska-Zajbert E. (red.), 2014, Nowe kierunki $w$ zarzadzaniu przedsiębiorstwem - wiodace orientacje, Wyd. Uniwersytetu Ekonomicznego we Wrocławiu, Wrocław.

Lisiecka K., 2002, Kreowanie jakości. Uwarunkowania, strategie, techniki, Wydawnictwo Akademii Ekonomicznej w Katowicach, Katowice.

Małachowski A., 1997, Metodologia tworzenia obiektowych systemów komunikacji gospodarczej, Wydawnictwo Akademii Ekonomicznej, Wrocław.

Nogalski B., Czapiewski R., 2012, Wpływ zarządzania procesowego na kształtowanie relacji z klientami na rynku dóbr i usług przemysłowych, Fmiles.pl Encykopedia Zarządzania, Kraków.

Nowosielski S. (red.), 2008, Procesy i projekty logistyczne, Wyd. Uniwersytetu Ekonomicznego we Wrocławiu, Wrocław.

Nowosielski S., 2009, Modelowanie procesów gospodarczych w literaturze i praktyce, Wyd. Uniwersytetu Ekonomicznego we Wrocławiu, Wrocław.

Nowosielski S. (red.), 2009, Podejście procesowe w organizacjach, Wyd. Uniwersytetu Ekonomicznego we Wrocławiu, Wrocław.

Obora H., 2008, Model architektury organizacji procesowej APQC, Uniwersytet Ekonomiczny w Krakowie, Kraków.

Osiadacz J., 2011, Narzędzia identyfikacji potrzeb innowacyjnych w przedsiębiorstwach, Polska Agencja Rozwoju Przedsiębiorczości, Warszawa.

Österle H., 1995, Business Engineering: Prozess- und Systementwicklung, Springer, Berlin.

Pawlak W.R. (red.), 2003, Poradnik menedżera jakości, Forum Media, Warszawa.

Polska Norma PN-EN ISO 9000:2000, Systemy zarzq̨dzania jakościq Podstawy i terminologia.

Romanowska M., Trocki M., 2004, Podejście procesowe w zarzązaniu, Szkoła Główna Handlowa, Warszawa.

Rummler G.A., Brache A.P., 2000, Podnoszenie efektywności organizacji, PWE, Warszawa. 
Schmelzer J., Sesselmann W., 2003, Geschäftsprozessmanagement in der Praxis, Hanser, Wien.

Stabryła A. (red.), 2006, Doskonalenie systemów zarządzania w społeczeństwie informacyjnym, Wydawnictwo Akademii Ekonomicznej w Krakowie, Kraków.

Stabryła A. (red.), 2008, Zarządzanie rozwojem organizacji $w$ społeczeństwie informacyjnym, t. 2, Uniwersytet Ekonomiczny w Krakowie, Kraków.

Stabryła A., Wawak S. (red.), 2012, Metody badania i modele rozwoju organizacji, Fmiles.pl Encyklopedia Zarządzania, Kraków.

Trocki M. (red.), 2011, Zarządzanie wiedzq w projektach, Oficyna Wydawnicza, Szkoła Główna Handlowa w Warszawie, Warszawa.

Trocki M., 2012, Nowoczesne zarządzanie projektami, Polskie Wydawnictwo Ekonomiczne, Warszawa.

\section{Materiały internetowe}

http://governica.com, Mapowanie procesów, Governica Encyklopedia, Zarządzanie jakością [dostępność 01.08.2018].
Gruchman G.B., Jak rozpocząć mapowanie procesów?, http://gruchman.pl [dostępność 05.01.2008]

Dobrowolska A., http://ioz.pwr.wroc.pl, Zarzq̨dzanie procesowe, rok akad. 2011/2012 [dostępność 01.08.2018].

Dobrowolska A., Postawy zarządzania jakościq. Normy ISO serii 9000 i inne normy zarządzania, Wykład, http://ioz.pwr.wroc.pl, [dostępność 01.08.2018].

Nowosielski S., Zarządzanie procesami - wykład, http://procesy.ue. wroc.pl, Uniwersytet Ekonomiczny we Wrocławiu [dostępność 01.08.2018].

Schemat blokowy, Wikipedia - Wolna Encyklopedia, http://pl.wikipedia.org [dostępność 01.08.2018].

Trocki M. (a), Zarzq̨dzanie procesowe. Materiały pomocnicze do wykładu na studiach doktoranckich, http://kolegia.sgh.waw.pl, Szkoła Główna Handlowa, Warszawa 2016 [dostępność 01.08.2018].

Trocki M. (b), Zarzadzanie projektami. Wykład, Katedra Zarządzania w Gospodarce Szkoła Główna Handlowa w Warszawie, http:// docplayer.pl, [dostępność 01.08.2018] 